\title{
Influence of Corn Silage Particle Length on the Performance of Lactating Dairy Cows Fed Supplemental Tallow
}

\author{
S. G. Onetti, R. D. Shaver, S. J. Bertics, and R. R. Grummer \\ Department of Dairy Science, \\ University of Wisconsin, Madison 53706-1284
}

\begin{abstract}
The objective of this study was to determine if the length of chop of processed corn silage influences the impact of supplemental fat on rumen fermentation and performance of dairy cows. We hypothesized that increasing forage particle length may alleviate the interference of fat on rumen fermentation. Sixteen Holstein cows averaging $120 \mathrm{~d}$ in milk were used in a replicated $4 \times 4$ Latin square design with 21 -d periods. Treatments were arranged as a $2 \times 2$ factorial with 0 or $2 \%$ tallow (dry matter basis), and corn silage harvested at either 19 or $32 \mathrm{~mm}$ theoretical length of cut. The forage:concentrate ratio was 50:50, and diets were formulated to contain $18 \%$ crude protein and $32 \%$ neutral detergent fiber (dry matter basis). Cows were allowed ad libitum consumption of diets that were fed twice daily as a total mixed ration. Fat supplemented cows had lower dry matter intake and produced less milk fat relative to nonsupplemented cows. No effect of corn silage particle length was observed for dry matter intake and milk fat production. Proportion of trans-10 C18:1 and of trans10, cis-12 conjugated linoleic acid was highest in milk fat of cows fed $2 \%$ supplemental tallow. Rumen $\mathrm{pH}$ was not affected by feeding tallow, and tended to be highest for cows eating the 32-mm theoretical length of chop corn silage diets. No effect of treatments was observed for rumen acetate-to-propionate ratio or rumen ammonia concentration. In this study, tallow supplementation had a negative impact on performance of dairy cows regardless of the corn silage particle length. Feeding tallow increased formation of trans-fatty acids in the rumen in the absence of significant changes in the rumen environment.
\end{abstract}

(Key words: corn silage, milk fat, particle size, tallow)

Abbreviation key: CLA = conjugated linoleic acid, $\mathbf{F A}=$ fatty acid, $\mathbf{M F D}=$ milk fat depression, $\mathbf{T L C}=$ theoretical length of chop.

Received December 19, 2002.

Accepted March 10, 2003.

Corresponding author: R. R. Grummer; e-mail: rgrummer@ facstaff.wisc.edu.

\section{INTRODUCTION}

Forage particle size may influence the effect of supplemental fats on animal performance. Increasing dietary particle size by replacing finely chopped alfalfa silage with coarse alfalfa hay tended to increase milk fat content and significantly increased rumination time when $11.6 \%$ whole roasted soybeans was included in the diet (Grant and Weidner, 1992). Conversely, Jenkins et al. (1998) reported a trend for greater FCM when 5\% tallow was fed with short alfalfa hay but not long alfalfa hay in diets containing $25 \%$ alfalfa silage, $25 \%$ corn silage, and $50 \%$ concentrate (DM basis).

Feeding processed corn silage to lactating cows has become a common practice among dairy producers. Some studies have shown increased milk production (Bal et al., 2000) and improved total tract starch digestion (Rojas-Bourrillon et al., 1987; Bal et al., 2000) when feeding processed corn silage. Processing increases rumen availability of starch due to kernel damage and also reduces corn silage particle size by approximately 15 to $30 \%$ (Johnson et al., 1999) at any given theoretical length of cut (TLC). A decrease in particle size in conjunction with higher availability of rapidly fermentable carbohydrate may reduce rumen $\mathrm{pH}$, impair fiber digestion, and decrease milk fat test.

Milk fat depression (MFD) occurs due to inhibition of milk fat synthesis by trans-C18:1 fatty acids (FA), specifically trans-10 C18:1, and its immediate precursor in the rumen, trans-10, cis-12 conjugated linoleic acid (CLA) (Bauman and Griinari, 2001). Under certain feeding practices, biohydrogenation pathways of polyunsaturated FA are shifted, leading to accumulation of these particular FA in the rumen. The presence of unsaturated FA, low ruminal $\mathrm{pH}$ and shifts in fermentation products due to low forage-to-concentrate ratio in the diet, or a combination of both, likely results in lower milk fat percentage and yield (Gaynor et al., 1995; Kalscheur et al., 1997; Griinari et al., 1998). With the increased use of high grain-yielding corn hybrids and kernel processors, the length of chop of corn silage may need to be increased to avoid excessive rates of carbohydrate fermentation in the rumen. Several studies have shown the positive relationship between forage particle 
size, time spent chewing (Grant and Weidner, 1992; Beauchemin et al., 1994), and reduced acid production in the rumen (Allen, 1997). The objective of this study was to examine the impact of corn silage particle length on rumen function and milk fat production of lactating dairy cows fed supplemental tallow in diets with processed high grain-yielding corn silage as the only forage source. We hypothesized that increasing corn silage particle length may alleviate the negative effects of tallow on milk fat depression previously observed in our laboratory (Onetti et al., 2001, 2002).

\section{MATERIALS AND METHODS}

\section{Animals}

Sixteen Holstein cows that averaged ( \pm SD) $120 \pm 8$ DIM and $673 \pm 77 \mathrm{~kg}$ BW were used in a replicated 4 $\times 4$ Latin square design with 21 -d periods. Two squares consisted of multiparous cows without rumen fistulas, one of multiparous cows with rumen fistulas, and one consisted of primiparous cows without fistulas. Cows within a square were assigned randomly to dietary treatments. Treatment sequences were ordered to minimize residual or carryover effects of any treatment in the succeeding period. Cows were housed individually in a tie-stall and stanchion barn and had free-choice access to water. All cows were injected with bovine somatotropin (Posilac, Monsanto Company, St. Louis, $\mathrm{MO}$ ) on the same day every $14 \mathrm{~d}$. Animals were handled according to the recommendations and procedures approved by the Research Animal Resources Center of the UW-Madison.

\section{Diets}

Experimental diets consisted of 50\% concentrate and $50 \%$ processed corn silage (DM basis). Treatments were arranged as a $2 \times 2$ factorial with 0 and $2 \%$ supplemental tallow (DM basis), and two forage treatments: corn silage harvested at $19-\mathrm{mm}$ TLC, and corn silage harvested at 32-mm TLC. The $19-\mathrm{mm}$ corn silage TLC was chosen because it is commonly used in the field with kernel processors, and the 32-mm TLC was used to test the effect of increasing TLC of processed corn silage. The roll clearance was set at $2 \mathrm{~mm}$. The corn hybrid used was Cargill 3677 (Cargill Inc., Minneapolis, MN), and was selected for high grain yield. Average corn silage DM, NDF, and CP was 38.0, 34.8, and 7.0\%, respectively. Ingredient composition of the experimental diets is shown in Table 1. Diets in the present study were formulated with the same ingredient composition as in Onetti et al. (2001). Diets were formulated to be isonitrogenous and to meet or exceed the National Research Council (NRC, 1989) nutrient allowances.
Tallow was added to the diets at expense of corn grain and soybean hulls, the two concentrate ingredients lowest in CP value. Urea was added to the diets to minimize the likelihood that $\mathrm{NH}_{3}-\mathrm{N}$ would be limiting for microbial growth (NRC, 2001). Tallow was incorporated into concentrates and then added to TMR. Fatty acid composition ( $\mathrm{g}$ of fatty acid/100 g DM) of tallow (Packerland Packing Co., Inc., Green Bay, WI) was 3\% C14:0, 25.1\% $\mathrm{C} 16: 0,2.7 \% \mathrm{C} 16: 1,19.7 \% \mathrm{C} 18: 0,42.1 \% \mathrm{C} 18: 1,3 \%$ $\mathrm{C} 18: 2,0.3 \% \mathrm{C} 18: 3$, and $4.1 \%$ others. Fatty acid composition was typical for tallow with an iodine value of 48 (NRC, 2001) and was similar to that of tallow used in our previous experiments (Onetti et al., 2001, 2002). Cows were fed the diets twice daily (0900 and $1800 \mathrm{~h})$ as a TMR to allow $10 \%$ feed refusal on an as-fed basis.

Chemical composition of experimental diets is shown in Table 2. Crude protein content was 0.6 percentage units higher for diets with supplemental tallow. The reason for increased $\mathrm{CP}$ content in tallow-containing diets is not clear, but it may be related to higher than expected CP values for soybean meal and distillers grains or a sampling or mixing error for that diet. Neutral detergent fiber content of diets containing tallow was, on average, 3 percentage units lower than diets without tallow. Lower inclusion of soybean hulls in diets with supplemental fat may account for the reduced $\mathrm{NDF}$ content. Concentration of calculated $\mathrm{NE}_{\mathrm{L}}$ was 0.08 $\mathrm{Mcal} / \mathrm{kg} \mathrm{DM}$ higher for fat-supplemented diets.

\section{Sampling and Laboratory Analysis}

Dry matter content of corn silage and concentrates was determined weekly using a $60^{\circ} \mathrm{C}$ forced-air oven; results were used to adjust as-fed ratios in the TMR. The TMR amount offered and refused was measured daily. Orts were collected on d 17 to 21 of each period and dried overnight in a $100^{\circ} \mathrm{C}$ forced-air oven for DMI determination. Corn silage and concentrate samples were collected weekly, dried $48 \mathrm{~h}$ in a $60^{\circ} \mathrm{C}$ forced-air oven, and ground to pass a 2-mm Wiley mill screen (Arthur H. Thomas, Philadelphia, PA). Organic matter was determined by oven drying at $550^{\circ} \mathrm{C}$ for $720 \mathrm{~min}$. Samples were analyzed for NDF (Mertens, 1999), CP (AOAC, 1990), and FA (Sukhija and Palmquist, 1988). The nonfibrous carbohydrate component was calculated as $100-(\mathrm{NDF}+$ ether extract $+\mathrm{CP}+$ ash $)$. Ether extract content was estimated from FA analysis as FA + 1 (NRC, 2001). Dietary $\mathrm{NE}_{\mathrm{L}}$ concentration was calculated from tabular values for individual feedstuffs and actual DMI using the NRC (2001) software. Corn silage particle size and distribution were determined using an oscillating screen particle separator according to the American Society of Agricultural Engineers standard S424 (ANSI, 1988). 
Table 1. Ingredient composition of experimental diets.

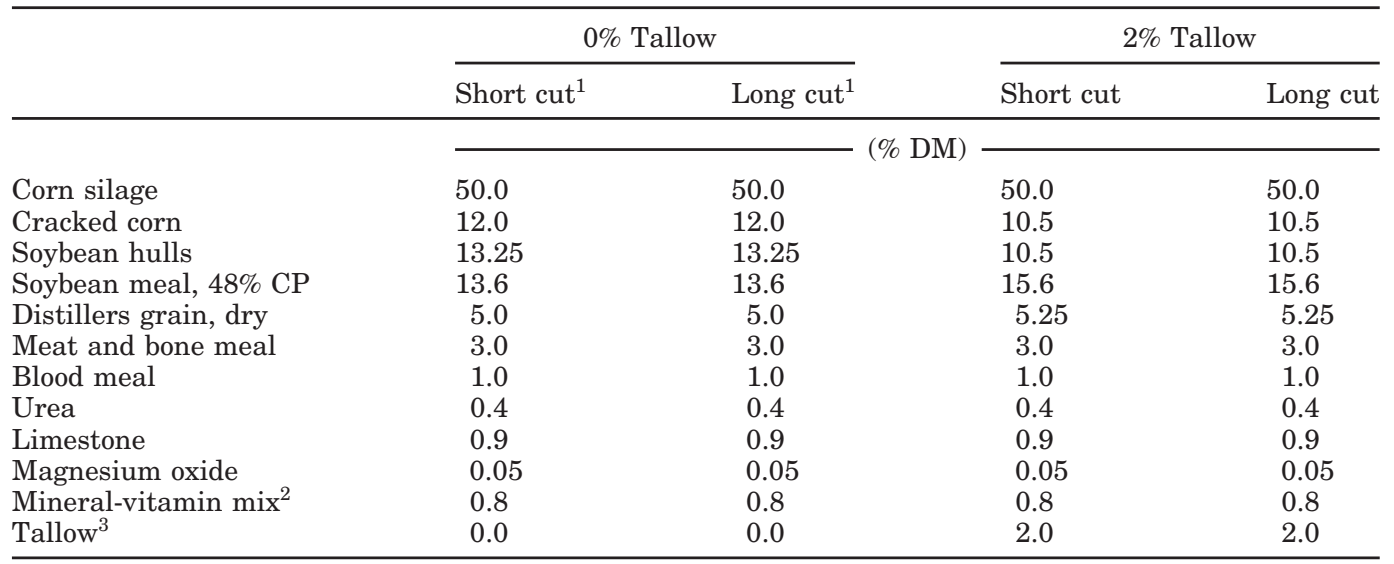

${ }^{1}$ Corn silage: Short cut $=19-\mathrm{mm}$ theoretical length of chop $(\mathrm{TLC})$; Long cut $=32-\mathrm{mm}$ TLC.

${ }^{2}$ Contained $0.55 \% \mathrm{Mn}, 0.55 \% \mathrm{Zn}, 0.35 \% \mathrm{Fe}, 0.14 \% \mathrm{Cu}, 0.008 \% \mathrm{I}, 0.006 \% \mathrm{Se}, 0.002 \% \mathrm{Co}, 3304 \mathrm{IU} / \mathrm{g}$ vitamin A, $1101 \mathrm{IU} / g$ vitamin $\mathrm{D}$, and $11 \mathrm{IU} / \mathrm{g}$ vitamin $\mathrm{E}$.

${ }^{3}$ Fatty acid composition (g of fatty acid/100 g DM) of tallow (Packerland Packing Co., Inc., Green Bay, WI) was $3 \% \mathrm{C} 14: 0,25.1 \% \mathrm{C} 16: 0,2.7 \% \mathrm{C} 16: 1,19.7 \% \mathrm{C} 18: 0,42.1 \% \mathrm{C} 18: 1,3 \% \mathrm{C} 18: 2,0.3 \% \mathrm{C} 18: 3$, and $4.1 \%$ others.

Cows were milked twice daily, and milk production was recorded at each milking during the final $7 \mathrm{~d}$ of each period. Milk samples from the a.m. and p.m. milking were collected on 5 consecutive days (d 17 to 21 of each period), and were analyzed for fat, $\mathrm{CP}$, and SNF by infrared analysis (AgSource Milk Analysis Laboratory, Menomonie, WI). Milk samples from d 18 and 19 were composited for fatty acid analysis. Milk fat was isolated as described by Stine et al. (1954). Fatty acid transesterification was performed according to the method described by Chouinard et al. (1999). Fatty acid methyl esters were injected into a gas chromatograph (Perkin Elmer Autosystem, Norwalk, CT) equipped with a 100$\mathrm{m}$ (i.d., $0.25 \mathrm{~mm}$ ) WCOT fused silica capillary column coated with CP-Sil 88 (Chrompack \#CP7489, Varian Inc., Walnut Creek, CA). Helium was utilized as the carrier gas. Three different runs were performed for

Table 2. Chemical composition of experimental diets.

\begin{tabular}{|c|c|c|c|c|}
\hline & \multicolumn{2}{|c|}{$0 \%$ Tallow } & \multicolumn{2}{|c|}{$2 \%$ Tallow } \\
\hline & Short cut ${ }^{1}$ & Long cut ${ }^{1}$ & Short cut & Long cut \\
\hline DM,\% & 0.54 & 0.53 & 0.54 & 0.53 \\
\hline $\mathrm{NE}_{\mathrm{L}}^{2}$ & 1.55 & 1.55 & 1.63 & 1.63 \\
\hline $\mathrm{CP}$ & 18 & 18 & 18.6 & 18.6 \\
\hline $\mathrm{NDF}$ & 31.6 & 31.1 & 28.6 & 28.1 \\
\hline Fatty acids & 3.3 & 3.4 & 5.4 & 5.5 \\
\hline $\mathrm{NFC}^{3}$ & 39.4 & 39.8 & 39.7 & 40.1 \\
\hline
\end{tabular}

\footnotetext{
${ }^{1}$ Corn silage: short cut $=19-\mathrm{mm}$ theoretical length of chop $(\mathrm{TLC})$; long cut $=32-\mathrm{mm}$ TLC.

${ }^{2} \mathrm{NRC}, 2001$.

${ }^{3} \mathrm{NFC}=$ nonfibrous carbohydrates.
}

each sample. Total fatty acid profile was determined using a temperature gradient run $\left(50\right.$ to $190^{\circ} \mathrm{C}$ at $4^{\circ} \mathrm{C} /$ min). An isothermal run $\left(160^{\circ} \mathrm{C}\right)$ was used to separate most trans-octadecenoic FA. A second isothermal run $\left(180^{\circ} \mathrm{C}\right)$ was used to separate trans- 15 , and trans-13/14 from cis-9 C18:1 that coelute as one peak during the isothermal run at $160^{\circ} \mathrm{C}$. Peaks were identified utilizing individual FA from Supelco Inc. (Bellefonte, PA), Sigma Chemical Co. (St. Louis, Mo), and Matreya Inc. (Pleasant Gap, PA). To convert area percentages to weight percentages, response correction factors for each fatty acid methyl ester were calculated utilizing a certified butter oil (CRM 164, Commission of the European Communities, Community Bureau of Reference, Brussels, Belgium).

Rumen fluid was sampled from fistulated cows before feeding $(0 \mathrm{~h})$ and at $2,4,6,8,10$, and $12 \mathrm{~h}$ after feeding on $d 20$. Cows were fed the total amount of feed at 0 $\mathrm{h}$ to ensure the availability of food during the entire collection period. Samples were taken from five different locations in the rumen with a metal filter probe. From nonfistulated cows, samples were taken at $4 \mathrm{~h}$ after feeding by rumenocentesis (Nordlund and Garrett, 1994). Rumen $\mathrm{pH}$ was determined immediately after the samples were collected (Twin $\mathrm{pH}$-meter Model B-213, Spectrum Technologies Inc., Plainfield, IL). One milliliter of rumen fluid was acidified with $20 \mu \mathrm{l}$ of $50 \% \mathrm{H}_{2} \mathrm{SO}_{4}$ and frozen until analysis for VFA by GLC (Perkin Elmer Autosystem, Norwalk, CT) as described by Bal et al. (2000), and $1 \mathrm{ml}$ was mixed with $20 \mu \mathrm{l}$ of $50 \%$ TCA and frozen until analysis for $\mathrm{NH}_{3}-\mathrm{N}$ (Chaney and Marbach, 1962). 
On d 18 and 19 of each period, 25- $\times 35$-cm Dacron polyester bags with an average $( \pm$ SD) pore size of $52 \pm$ $5 \mu \mathrm{m}$ (R102 Marvelaire White, N. Erlanger, Blumgardt and Co., Inc. New York, NY) were incubated in triplicate in the rumen for 12,24 , and $48 \mathrm{~h}$ to determine in situ $\mathrm{DM}$ and NDF disappearance of corn silage. Bags containing on average ( \pm SD) $22.5 \pm 0.49 \mathrm{~g} \mathrm{DM}$ of undried and unground corn silage were placed in a nylon laundry bag in the ventral sac of the rumen. After incubation, bags were washed in a commercial washing machine with cold water for three cycles of 15 min each (Cherney et al., 1990). Bags were dried at $60^{\circ} \mathrm{C}$ in a forced-air oven for $48 \mathrm{~h}$ to determine DM disappearance. Residues from triplicate bags were composited for NDF analysis.

\section{Statistics}

All data were analyzed as a $4 \times 4$ replicated Latin square with a factorial arrangement of treatments using the mixed procedure of SAS (SAS User's Guide, 1998).

For DMI, milk yield and composition data, and rumen measurements at $4 \mathrm{~h}$ after feeding the model included the effects of square, period, fat ( $0 \%$ and $2 \%$ tallow), forage (19-mm and 32-mm TLC), and fat $\times$ forage. Square $\times$ fat, square $\times$ forage, square $\times$ fat $\times$ forage, period $\times$ fat, period $\times$ forage, and period $\times$ fat $\times$ forage were removed from the model because $P$ was $>0.25$. Cow within square was the specified term for the random statement.

Ruminal $\mathrm{pH}, \mathrm{NH}_{3}-\mathrm{N}$, and VFA from fistulated cows, and in situ DM and NDF degradability were analyzed by time as repeated measures. The model included period, fat, forage, fat $\times$ forage, time, time $\times$ fat, time $\times$ forage, and time $\times$ fat $\times$ forage. The terms specified for the random statement were cow and cow $\times$ period $\times$ fat $\times$ forage. The covariance structure used to fit the model was selected based on the Akaike's Information Criterion of the mixed models of SAS (SAS User's Guide, 1998).

Least square means are reported throughout. Unless otherwise stated, significance was declared at $P<0.05$. Trends towards significance were considered at $0.05 \leq$ $P<0.15$.

\section{RESULTS AND DISCUSSION}

Particle size distribution and mean particle length of the short- and long-cut corn silage is presented in Table 3. Mean particle size was $9.3 \mathrm{~mm}$ for the shortand $9.7 \mathrm{~mm}$ for the long-cut corn silage. However, increasing length of chop without changing roll clearance increased percentage of as-fed sample retained on the
Table 3. Particle size distribution (\% of sample on screen, wet basis), and mean particle length of short- and long-cut corn silage. ${ }^{1}$

\begin{tabular}{lcccc}
\hline & Short cut & SD & Long cut & SD \\
\hline Screen size ${ }^{2}$ mm & & & & \\
26.9 & 1.8 & 0.5 & 8.7 & 1.4 \\
18.0 & 27.0 & 4.6 & 25.7 & 1.5 \\
8.98 & 34.0 & 3.3 & 25.3 & 1.2 \\
5.61 & 14.6 & 1.3 & 15.0 & 0.9 \\
1.65 & 17.4 & 1.5 & 18.7 & 1.5 \\
Pan & 5.0 & 1.0 & 6.5 & 2.1 \\
MPS ${ }^{3}$ mm & 9.3 & 0.4 & 9.7 & 0.7 \\
\hline
\end{tabular}

${ }^{1}$ Short cut $=19-\mathrm{mm}$ theoretical length of chop (TLC); long cut = 32-mm TLC.

${ }^{2}$ Square hole diagonal.

${ }^{3} \mathrm{MPS}=$ Geometric mean particle size.

top screen by 6.9 percentage units, with little effect on percentage retained on the second screen. Percentage retained on the third screen was lower for the long-cut corn silage (34.0 and $25.3 \%$ for the $19-\mathrm{mm}$ and the 32 $\mathrm{mm}$ TLC corn silage, respectively). Difference in percentage retained on the fourth and fifth screens and the pan was small. Schwab et al. (2002) observed a similar particle size distribution when comparing corn silages with the same TLC used in the present study. Increasing corn silage TLC had a modest impact on mean particle size but changed particle size distribution with an increased proportion of particles $>26.9 \mathrm{~mm}$ and a decreased proportion of particles retained on the third screen. Particle size distribution is probably more important than mean particle size when formulating dairy diets to be adequate in physically effective fiber (Mertens, 1997; Heinrichs, et al., 1999). Studies designed exclusively to evaluate the effect of particle size distribution on animal performance are not available. Recently, Leonardi et al. (2001) tested diets with similar mean particle size and observed that diets with a broad versus narrower particle size distribution resulted in a trend for increased chewing time per kilogram of DMI.

Dry matter intake was $1.6 \mathrm{~kg} / \mathrm{d}$ lower $(P<0.001)$ for tallow-supplemented cows (Table 4). Intake of calculated $\mathrm{NE}_{\mathrm{L}}$ was not affected by feeding tallow (40.5 vs. $40.1 \mathrm{Mcal} / \mathrm{d}$ for 0 and $2 \%$ supplemental tallow, respectively). A similar response to $2 \%$ supplemental tallow was observed in our previous studies with corn silage as the only forage source (Onetti et al., 2001, 2002). Cows fed $19-\mathrm{mm}$ TLC corn silage tended $(P<0.07)$ to consume $0.75 \mathrm{~kg}$ DM/d more than cows fed $32-\mathrm{mm}$ TLC silage, and tended $(P<0.07)$ to have higher intake of $\mathrm{NE}_{\mathrm{L}}$. Several studies have indicated a lack of effect of chop length of corn silage on DMI of dairy cows. Similar DMI was observed for cows consuming processed corn silage harvested at a 9.5-, 14-, and 19-mm TLC (Bal et al., 2000). Feeding unprocessed fine- or coarse-chopped corn silage (mean particle size of 3.4 and $7.6 \mathrm{~mm}$, re- 
Table 4. Least square means for $\mathrm{DM}, \mathrm{NE}_{\mathrm{L}}$, and $\mathrm{NDF}$ intake.

\begin{tabular}{|c|c|c|c|c|c|c|c|c|}
\hline & \multicolumn{2}{|c|}{$0 \%$ tallow } & \multicolumn{2}{|c|}{$2 \%$ tallow } & \multirow[b]{2}{*}{$\mathrm{SE}$} & \multicolumn{3}{|c|}{ Significance $(P<)^{1}$} \\
\hline & Short cut ${ }^{2}$ & Long cut ${ }^{2}$ & Short cut & Long cut & & $\mathrm{T}$ & $\mathrm{L}$ & $\mathrm{T} \times \mathrm{L}$ \\
\hline DMI (kg/d) & 26.7 & 25.5 & 24.7 & 24.5 & 0.8 & 0.001 & 0.07 & NS \\
\hline $\mathrm{NE}_{\mathrm{L}} \mathrm{I}(\mathrm{Mcal} / \mathrm{d})^{3}$ & 41.4 & 39.5 & 40.3 & 39.9 & 1.3 & NS & 0.07 & NS \\
\hline NDFI $(\mathrm{kg} / \mathrm{d})^{4}$ & 8.3 & 7.7 & 6.9 & 6.7 & 0.2 & 0.001 & 0.001 & NS \\
\hline
\end{tabular}

${ }^{1} \mathrm{~T}=$ main effect of tallow; $\mathrm{L}=$ main effect of length of cut, and $\mathrm{T} \times \mathrm{L}=$ interaction; $\mathrm{NS}=$ nonsignificant.

${ }^{2}$ Corn silage: short cut $=19$-mm theoretical length of chop (TLC); long cut $=32-\mathrm{mm}$ TLC.

${ }^{3} \mathrm{NE}_{\mathrm{L}} \mathrm{I}=\mathrm{NE}_{\mathrm{L}}$ intake.

${ }^{4} \mathrm{NDFI}=\mathrm{NDF}$ intake.

spectively) had no effect on DMI (Clark and Armentano, 1998). However, these studies used corn silage that was chopped at a finer TLC than the corn silage fed in our study. Schwab et al. (2002) observed a $0.8 \mathrm{~kg} / \mathrm{d}$ decrease in DMI of dairy cows in midlactation when the TLC of processed brown-midrib corn silage was increased from 19 to $32 \mathrm{~mm}$. A decrease in DMI was also observed by Timmermans et al. (2000) when feeding 40- vs. 30-mm TLC processed corn silage to midlactation cows. The reason for decreased DMI with increased corn silage TLC above $19 \mathrm{~mm}$ is not evident. Increasing forage particle length probably increased rumen retention time of particulate matter resulting in increased rumen fill and reduced voluntary feed intake. Allen and Grant (2000) showed that increasing the proportion of longer particles in diets containing wet corn gluten feed decreased ruminal rate of passage. Decreased rate of particulate passage from the rumen with increased forage particle length was also reported by Rode and Satter (1988). However, Bal et al. (2000) observed similar solids passage rate when processed corn silage length of chop was increased from 9.5 to $19 \mathrm{~mm}$.

Feed refusals were analyzed for NDF content to calculate NDF intake adjusted by NDF of orts. Neutral detergent fiber intake was $1.2 \mathrm{~kg} / \mathrm{d}$ lower $(P<0.001)$ for cows that received supplemental tallow (Table 4), likely due to the lower NDF content of these diets and decreased DMI. Increasing TLC reduced $(P<0.001)$ NDF intake by $0.4 \mathrm{~kg} / \mathrm{d}$. The decrease in NDF intake observed with increased TLC was probably driven by lower DMI of cows consuming these diets.

Table 5 shows rumen data corresponding to cannulated animals $(n=4)$ that were analyzed by time as repeated measurements. Data corresponding to the total number of animals used $(\mathrm{n}=16)$ at $4 \mathrm{~h}$ after feeding are similar to the results presented in Table 5, unless otherwise stated. No significant fat $\times$ time, forage $\times$ time, or fat $\times$ forage $\times$ time interactions were detected for any of the variables measured. Ruminal $\mathrm{pH}$ was not affected by supplemental tallow. There was a trend ( $P$ $<0.09$ ) for higher ruminal $\mathrm{pH}$ as corn silage TLC was increased from 19 to $32 \mathrm{~mm}$. Ruminal $\mathrm{pH}$ at $4 \mathrm{~h}$ post- feeding was 0.2 units lower $(P<0.08)$ for cows fed the short-cut corn silage (5.7 vs. 5.9 for 19 - and $32-\mathrm{mm}$ TLC corn silage, respectively). Decreased DMI was likely the reason for higher rumen $\mathrm{pH}$ with increased corn silage TLC.

Dietary treatments had no effect on ruminal $\mathrm{NH}_{3}-\mathrm{N}$. This is in disagreement with our previous observations (Onetti et al., 2001) in which the inclusion of tallow in the diets caused a reduction in rumen $\mathrm{NH}_{3}-\mathrm{N}$ concentration. Others (Bal et al., 2000; Schwab et al., 2002) have reported no effect of increasing corn silage TLC on rumen $\mathrm{NH}_{3}-\mathrm{N}$ concentration.

Concentration of total VFA in the rumen tended ( $P$ $<0.11)$ to decrease when fat was added to the diets (Table 5). Lower concentration of VFA might be explained by the lower DMI of cows receiving $2 \%$ tallow. The molar proportion of acetate and propionate, and acetate to propionate ratio were not affected by supplemental tallow. However, at $4 \mathrm{~h}$ postfeeding there was a significant $(P<0.005)$ reduction in the molar proportion of acetate when tallow was included in the diets; no effect was observed for propionate or the acetate-topropionate ratio at $4 \mathrm{~h}$ postfeeding. Molar proportions of isobutyrate $(P<0.03)$ and isovalerate $(P<0.02)$ were significantly increased. Molar proportion of butyrate was lowest $(P<0.03)$ for cows fed the 32 -mm TLC corn silage plus $2 \%$ tallow treatment. The biological significance of these changes is questionable because of the low magnitude of change. Corn silage TLC did not affect total VFA concentration or molar proportion of individual VFA. These results agree with those of Bal et al. (2000) and Schwab et al. (2002).

In situ DM and NDF disappearance were not affected by dietary treatments (data not shown). No effect of supplemental tallow on NDF degradability was observed in our previous studies (Onetti et al., 2001, 2002). Forty-eight hour NDF corn silage disappearance averaged $21.9 \%$.

Table 6 shows milk production and milk composition data as affected by dietary treatments. No effect of supplemental tallow was observed for milk yield. Lack of milk production response might be explained by lower 
Table 5. Ruminal pH, concentration of total VFA and ammonia, and molar proportion of VFA.

\begin{tabular}{|c|c|c|c|c|c|c|c|c|}
\hline & \multicolumn{2}{|c|}{$0 \%$ Tallow } & \multicolumn{2}{|c|}{$2 \%$ Tallow } & \multirow[b]{2}{*}{ SE } & \multicolumn{3}{|c|}{ Significance $(P<)^{1}$} \\
\hline & Short cut ${ }^{2}$ & Long cut ${ }^{2}$ & Short cut & Long cut & & $\mathrm{T}$ & $\mathrm{L}$ & $\mathrm{T} \times \mathrm{L}$ \\
\hline $\mathrm{pH}$ & 6.1 & 6.2 & 6.1 & 6.2 & 0.1 & NS & 0.09 & NS \\
\hline $\mathrm{NH}_{3}-\mathrm{N}(\mathrm{mg} / \mathrm{dl})$ & 14.7 & 15.2 & 17.1 & 14.8 & 1.7 & NS & NS & NS \\
\hline $\mathrm{VFA}(\mathrm{m} M)$ & 109.2 & 105.9 & 103.4 & 97.9 & 4.7 & 0.11 & NS & NS \\
\hline Acetate & 590 & 590 & 581 & 502 & 16 & NS & NS & NS \\
\hline Propionate & 27.2 & 26.3 & 26.1 & 27.0 & 1.5 & NS & NS & NS \\
\hline Butyrate & 10.1 & 10.7 & 11.4 & 9.6 & 0.8 & NS & NS & 0.03 \\
\hline Isobutyrate & 0.54 & 0.57 & 0.67 & 0.64 & 0.04 & 0.03 & NS & NS \\
\hline Isovalerate & 1.31 & 1.39 & 1.75 & 1.61 & 0.10 & 0.02 & NS & NS \\
\hline Valerate & 1.85 & 1.91 & 1.95 & 1.89 & 0.09 & NS & NS & NS \\
\hline $\mathrm{A}: \mathrm{P}^{3}$ & 2.20 & 2.29 & 2.31 & 2.28 & 0.18 & NS & NS & NS \\
\hline
\end{tabular}

DMI of cows fed supplemental tallow (Table 4). The decrease in DMI was enough to offset higher energy content of tallow-containing diets, resulting in similar $\mathrm{NE}_{\mathrm{L}}$ intake for cows consuming diets with and without supplemental fat. Yield of $4 \% \mathrm{FCM}$ was $2.3 \mathrm{~kg} / \mathrm{d}$ lower $(P<0.001)$ for cows fed supplemental tallow, mainly as a result of lower milk fat production (Table 6). Milk and $4 \% \mathrm{FCM}$ production were unaffected by corn silage TLC. Others (Bal et al., 2000; Schwab et al., 2002) have reported no effect of increasing processed corn silage TLC on milk yield.

There was a trend $(P<0.11)$ for increased milk protein percentage when fat was added to the diets. Contrary to these results, concentration of protein in milk is usually decreased when supplemental fats are fed due to increased milk production (Wu and Huber, 1994). The reason for a tendency to increased milk protein percentage in this study is not clear. We observed a similar effect in a previous study (Onetti et al., 2001), where feeding 2 or $4 \%$ supplemental fat to cows fed corn silage as the only forage source resulted in increased milk protein percentage. In that study, higher milk protein probably was a result of decreased milk production. However, milk production in the present study was not affected by supplemental fat. A trend ( $P$ $<0.12$ ) for a tallow $\times$ TLC interaction was observed for milk protein yield. Long-cut corn silage decreased milk protein yield in cows fed diets without tallow, probably because of numerical lower milk production. On the other hand, cows fed $2 \%$ supplemental tallow produced more milk protein when the long TLC corn silage was fed. This increase, however, was very small. Solids-notfat concentration in milk was not affected by dietary treatments.

Contrary to our expectations, no interaction between tallow supplementation and corn silage TLC was observed for milk fat percentage and milk fat yield (Table 6), indicating that increasing TLC from 19 to $32 \mathrm{~mm}$ did not lessen the negative effects of tallow on rumen function. Milk fat percentage and yield decreased $(P<$ 0.001 ) when $2 \%$ tallow was included in the diets. A similar response to feeding $2 \%$ tallow on corn silagebased diets was observed in our previous studies (Onetti el al., 2001, 2002). As in these previous studies, the cause of MFD is not entirely clear. We did not observe any major effects of supplemental tallow on rumen mea-

Table 6. Least square means for milk yield and composition.

\begin{tabular}{|c|c|c|c|c|c|c|c|c|}
\hline & \multicolumn{2}{|c|}{$0 \%$ Tallow } & \multicolumn{2}{|c|}{$2 \%$ Tallow } & \multirow[b]{2}{*}{$\mathrm{SE}$} & \multicolumn{3}{|c|}{ Significance $(P<)^{1}$} \\
\hline & Short cut ${ }^{2}$ & Long cut ${ }^{2}$ & Short cut & Long cut & & $\mathrm{T}$ & $\mathrm{L}$ & $\mathrm{T} \times \mathrm{L}$ \\
\hline Milk, kg/d & 42.6 & 41.0 & 40.8 & 41.0 & 1.4 & NS & NS & NS \\
\hline $4 \%$ FCM, kg/d & 35.5 & 34.7 & 32.6 & 32.9 & 1.3 & $<0.001$ & NS & NS \\
\hline Fat, $\%$ & 2.92 & 3.02 & 2.71 & 2.72 & 0.12 & $<0.001$ & NS & NS \\
\hline Fat, kg/d & 1.23 & 1.23 & 1.10 & 1.10 & 0.06 & $<0.001$ & NS & NS \\
\hline Protein, \% & 3.20 & 3.20 & 3.24 & 3.24 & 0.07 & 0.11 & NS & NS \\
\hline Protein, kg/d & 1.35 & 1.30 & 1.30 & 1.32 & 0.05 & NS & NS & 0.12 \\
\hline $\mathrm{SNF}, \%$ & 8.94 & 8.92 & 8.93 & 8.93 & 0.09 & NS & NS & NS \\
\hline
\end{tabular}

${ }^{1} \mathrm{~T}=$ main effect of tallow; $\mathrm{L}=$ main effect of length of cut, and $\mathrm{T} \times \mathrm{L}=$ interaction; $\mathrm{NS}=$ nonsignificant.

${ }^{2}$ Corn silage: Short cut $=19$-mm theoretical length of chop (TLC); long cut $=32$-mm TLC. 
Table 7. Least square means for milk fatty acid composition of milk fat.

\begin{tabular}{|c|c|c|c|c|c|c|c|c|}
\hline & \multicolumn{2}{|c|}{$0 \%$ Tallow } & \multicolumn{2}{|c|}{$2 \%$ Tallow } & \multirow[b]{2}{*}{$\mathrm{SE}$} & \multicolumn{3}{|c|}{ Significance $(P<)^{1}$} \\
\hline & Short cut ${ }^{2}$ & Long cut ${ }^{2}$ & Short cut & Long cut & & $\mathrm{T}$ & $\mathrm{L}$ & $\mathrm{T} \times \mathrm{L}$ \\
\hline Profile & \multicolumn{8}{|c|}{$\longrightarrow \mathrm{g} / 100 \mathrm{~g}$ of FA } \\
\hline C4 to $\mathrm{C} 14$ & 26.75 & 27.29 & 23.37 & 23.17 & 0.60 & $<0.001$ & NS & NS \\
\hline $\mathrm{C} 16: 0$ & 28.27 & 27.75 & 28.34 & 27.63 & 0.62 & NS & 0.06 & NS \\
\hline C18:0 & 7.52 & 7.72 & 8.16 & 8.19 & 0.30 & 0.01 & NS & NS \\
\hline C18:1 & 22.43 & 22.50 & 25.40 & 25.83 & 0.62 & $<0.001$ & NS & NS \\
\hline \multicolumn{9}{|l|}{$\mathrm{C} 18: 1$ isomers } \\
\hline trans $-6 / 8$ & 0.39 & 0.36 & 0.59 & 0.59 & 0.03 & $<0.001$ & NS & NS \\
\hline trans -9 & 0.28 & 0.27 & 0.43 & 0.41 & 0.02 & $<0.001$ & NS & NS \\
\hline trans -10 & 1.20 & 1.16 & 1.98 & 1.97 & 0.18 & $<0.001$ & NS & NS \\
\hline trans -11 & 0.57 & 0.63 & 0.42 & 0.40 & 0.04 & $<0.001$ & NS & NS \\
\hline trans -12 & 0.30 & 0.36 & 0.38 & 0.30 & 0.04 & NS & NS & 0.14 \\
\hline$c i s-9$ & 17.53 & 18.35 & 19.31 & 20.14 & 0.63 & $<0.001$ & 0.10 & NS \\
\hline cis-11/12 & 0.86 & 0.91 & 0.96 & 0.90 & 0.05 & NS & NS & NS \\
\hline $\mathrm{CLA}^{3}$ c9t11 & 0.57 & 0.54 & 0.42 & 0.51 & 0.04 & $<0.01$ & $\mathrm{NS}$ & 0.06 \\
\hline $\mathrm{CLA}^{3} \mathrm{t} 10 \mathrm{c} 12$ & 0.01 & 0.01 & 0.03 & 0.03 & 0.01 & $<0.001$ & NS & NS \\
\hline C18:2 & 4.30 & 4.26 & 3.79 & 3.77 & 0.13 & $<0.001$ & NS & NS \\
\hline C18:3 & 0.27 & 0.28 & 0.23 & 0.23 & 0.01 & $<0.001$ & NS & NS \\
\hline Other & 9.81 & 9.63 & 10.33 & 10.56 & 0.37 & 0.001 & NS & NS \\
\hline Total trans ${ }^{4}$ & 3.39 & 3.39 & 4.15 & 4.20 & 0.25 & $<0.001$ & NS & NS \\
\hline
\end{tabular}

${ }^{1} \mathrm{~T}=$ main effect of tallow; $\mathrm{L}=$ main effect of length of cut, and $\mathrm{T} \times \mathrm{L}=$ interaction; $\mathrm{NS}=$ nonsignificant.

${ }^{2}$ Corn silage: Short cut $=19-\mathrm{mm}$ theoretical length of chop (TLC); long cut $=32$-mm TLC.

${ }^{3} \mathrm{CLA}=$ Conjugated linoleic acid.

${ }^{4}$ trans-C18:1 isomers plus cis-9, trans-11 CLA and trans-10, cis-12 conjugated linoleic acid.

surements (Table 5). However, milk fat of cows receiving supplemental tallow contained a higher proportion of total trans-C18:1 FA (Table 7). The negative relationship between milk fat percentage and trans-FA in milk fat has been well documented (Bauman and Griinari, 2001). Low ruminal $\mathrm{pH}$ inhibits complete biohydrogenation of polyunsaturated FA and leads to an increased flow of trans-C18:1 FA to the duodenum and their incorporation into milk fat (Kalscheur et al., 1997). Although there was a trend for a higher $\mathrm{pH}$ in the rumen of cows fed the 32-mm relative to cows fed the 19-mm TLC corn silage, we did not observe any tallow $\times$ TLC interaction for milk fat percentage or milk fat yield. The $\mathrm{pH}$ range at which hydrogenation of FA in the rumen is affected needs to be determined. Tallow-containing diets in the present study were 3 percentage units lower in NDF than diets without supplemental tallow. Grant and Weidner (1992) indicated that fat was less likely to negatively affect milk fat test at high dietary NDF concentration. However, Ruppert et al. (2003) observed a linear decrease in milk fat percentage when increased levels of supplemental tallow were fed with diets that were similar in NDF concentration and had corn silage as the only forage source.

Increasing corn silage TLC had no effect on milk fat percentage or yield (Table 6). Similarly, milk fat percentage and yield were not affected by increasing processed corn silage TLC from 9.5 to $19 \mathrm{~mm}$ (Bal et al., 2000) or from 19 to $32 \mathrm{~mm}$ (Schwab et al., 2002). Al- though longer TLC resulted in a trend for higher ruminal $\mathrm{pH}$, it was not reflected in changes in milk fat fatty acid composition, suggesting that hydrogenation of FA in the rumen was not affected.

Overall, milk fat concentration in this study was low for all treatments. Although NDF concentration of diets was above recommendations (NRC, 2001), it might not have been adequate to maintain milk fat production of midlactation cows consuming high corn silage diets rich in rapidly fermentable starch. The inclusion of tallow in this type of diet supplied more precursors for the formation of trans-FA in the rumen, which may have resulted in a more pronounced MFD. Previous research in our laboratory (Onetti et al., 2002) showed a linear increase in milk fat percentage and milk fat yield as the ratio of alfalfa silage to corn silage was increased in the diets where NDF concentration was held constant. This suggests that the minimum amount of NDF necessary to avoid milk fat depression is probably higher for diets high in corn silage. However, rumen function may not have been compromised in this study, as indicated by ruminal $\mathrm{pH}>6$ and high DMI. We hypothesized that increasing corn silage TLC would prevent milk fat depression associated with high availability of rapidly fermentable carbohydrates. However, no beneficial effect of corn silage TLC was observed for milk fat percentage or yield in this study.

Milk fat fatty acid composition is presented in Table 7. Changes in the proportion of FA in milk fat were 
similar to our previous results (Onetti et al., 2001; Onetti et al., 2002) and consistent with the literature. The changes in milk fat composition observed are in accordance to changes that occur during dietary induced MFD (Bauman and Griinari, 2001). In this study, the proportion of short- and medium-chain FA (C4 to C14) was decreased $(P<0.001)$ with supplemental tallow. No effect of supplemental tallow was observed for C16:0 probably due to the significant amount provided by tallow. Milk fat content of short and medium-chain FA is usually decreased because of the greater reduction of de novo FA synthesis in mammary gland; as a consequence, content of long-chain FA is increased during MFD. Overall, the proportion of total C18 FA (sum of C18:0, C18:1, C18:2, C18:3, and cis-9, trans-11 and trans-10, cis-12 CLA) was significantly higher ( $P$ $<0.001$, data not shown) when supplemental tallow was fed despite the variable response of individual C18 FA. Proportions of C18:0 and C18:1 were significantly increased $(P=0.01$ and $P<0.001$, respectively) in milk fat of cows fed $2 \%$ supplemental tallow. Concentrations of C18:2 and C18:3 were decreased $(P<0.001)$ when supplemental tallow was fed. There was a significant reduction $(P<0.01)$ in the proportion of cis-9, trans11 CLA when tallow was added to the diets, and this decrease tended to be more pronounced for cows fed the 19-mm TLC corn silage (tallow $\times$ TLC interaction, $P=$ 0.06 ). The trans-10, cis-12 CLA isomer was significantly higher $(P<0.001)$ in milk fat of cows fed supplemental fat.

Including $2 \%$ supplemental tallow in the diets significantly increased $(P<0.001)$ the proportions of trans6/8, trans-9 and trans-10 C18:1 in milk fat, decreased $(P<0.001)$ the proportion of trans-11 C18:1, and did not affect the proportion of trans-12 C18:1. Proportion of total trans-C18:1 in milk fat increased $(P<0.001)$ one percentage unit when tallow was added to the diets (data not shown). Using the equation developed by Griinari et al. (1998) evaluating 13 studies and 19 individual treatments, 1 percentage unit increase in transC18:1 would correspond to 0.2 percentage units decrease in milk fat percentage. Consistent with these results, milk fat content of cows fed supplemental tallow in this study was 0.25 percentage units lower than that of cows fed control diets. Relative percentage of cis-9 C18:1 significantly increased $(P<0.001)$ and that of cis-11/12 did not change with supplemental tallow. Concentration of total trans-FA, i.e. trans-C18:1 isomers plus cis-9, trans-11 and trans-10, cis-12 CLA, was significantly higher $(P<0.001)$ in milk of cows fed supplemental tallow. The presence of certain intermediates of biohydrogenation in milk fat, especially trans-10 C18:1 and trans-10, cis-12 CLA, have been consistently associated with MFD (Griinari et al., 1998; Chouinard et al., 1999). We demonstrated in a previous study (Onetti et al., 2001) that the increase in trans-10 FA (trans-10 C18:1 plus trans-10, cis-12 CLA) was independent of the overall increase in C18 FA that occurs during MFD. Based on results of this study and of previous research (Onetti et al., 2001, 2002), changes in rumen environment that result in MFD and shift in biohydrogenation pathways with formation of trans-FA, appear to be subtle.

Corn silage TLC had minimal effect on relative proportions of FA in milk fat. Proportion of C16:0 tended $(P=0.06)$ to be lower in milk fat of cows fed the $32-\mathrm{mm}$ corn silage. No effects of corn silage TLC were observed on the proportion of the different C18:1 isomers, except for a trend $(P=0.10)$ of increased cis-9 C18:1 when the 32-mm TLC corn silage was fed. No interaction of tallow and corn silage TLC was observed for total trans-FA in milk fat, which is in agreement with results obtained for milk fat percentage and composition.

\section{CONCLUSIONS}

Including $2 \%$ tallow in diets with corn silage as the only forage source resulted in decreased DMI and milk fat production, regardless of corn silage TLC. Formation of trans-10 C18:1 and trans-10, cis-12 CLA intermediates in the rumen and their incorporation in milk fat is an indication of shifts in bacterial biohydrogenation pathways. We hypothesized that increasing corn silage TLC would alleviate the negative effects of tallow on rumen function when corn silage-based diets are fed. However, no interaction of corn silage TLC and tallow supplementation was observed for milk fat production in this study. Milk fat of cows that experienced MFD had a higher proportion of trans-10 C18:1 and of trans10, cis-12 CLA. The ability to detect a tallow-induced MFD in this study was not associated with marked changes in rumen fermentation.

\section{ACKNOWLEDGMENTS}

The authors thank the UW Arlington Agricultural Research Station crew for animal care and feeding. Appreciation is expressed to Packerland Packing Co., Inc. (Green Bay, WI) for donating the tallow and to Fats and Proteins Research Foundation for partial funding of the project.

\section{REFERENCES}

Allen, M. S. 1997. Relationship between fermentation acids production in the rumen and the requirement of physically effective fiber. J. Dairy Sci. 80:1447-1462.

Allen, D. M., and R. J. Grant. 2000. Interactions between forage and wet corn gluten feed as sources of fiber in diets for lactating dairy cows. J. Dairy Sci. 83:322-331. 
American National Standards Institute. 1988. Method of determining and expressing particle size of chopped forage materials for screening. ASAE S424.

Association of Official Analytical Chemists. 1990. Official Methods of Analysis. Vol. I. 15th ed. AOAC, Arlington, VA.

Bal, M. A., R. D. Shaver, A. G. Jirovec, K. J. Shinners, and J. G. Coors. 2000. Crop processing and chop length of corn silage: Effects on intake, digestion, and milk production by dairy cows. J. Dairy Sci. 83:1264-1273.

Bauman, D. E., and J. M. Griinari. 2001. Regulation and nutritional manipulation of milk fat: Low-fat milk syndrome. Livest. Prod. Sci. 70:15-29.

Beauchemin, K. A., B. I. Farr, L. M. Rode, and G. B. Schaalje. 1994. Effects of alfalfa silage chop length and supplementary long hay on chewing and milk production of dairy cows. J. Dairy Sci. 77:1326-1339.

Chaney, A. L. and E. P. Marbach. 1962. Modified reagents for determination of urea and ammonia. Clin. Chem. 8:130-132.

Cherney, D. J. R., J. A. Patterson, and R. P. Lemenager. 1990. Influence of in situ bag rinsing technique on determination of dry matter disappearance. J. Dairy Sci. 73:391-397.

Chouinard, P. Y., L. Corneau, D. M. Barbano, L. E. Metzger, and D. E. Bauman. 1999. Conjugated linoleic acids alter milk fatty acid composition and inhibit milk fat secretion in dairy cows. J. Nutr. 129:1579-1584.

Clark, P. W., and L. E. Armentano. 1999. Influence of particle size on the effectiveness of the fiber in corn silage. J. Dairy Sci. 82:581-588.

Gaynor, P. J., D. R. Waldo, A. V. Capuco, R. D. Erdman, L. W. Douglass, and B. B. Teter. 1995. Milk fat depression, the glucogenic theory, and trans-C $\mathrm{C}_{18: 1}$ FA. J Dairy Sci. 78:2008-2015.

Grant, R. J., and S. J. Weidner. 1992. Effect of fat from whole soybeans on performance of dairy cows fed rations differing in fiber level and particle size. J. Dairy Sci. 75:2742-2751.

Griinari, J. M., D. A. Dwyer, M. A. McGuire, D. E. Bauman, D. L. Palmquist, and K. V. V. Nurmela. 1998. trans-octadecenoic acids and milk fat depression in lactating dairy cows. J. Dairy Sci. 81:1251-1261.

Heinrichs, A. J., D. R. Buckmaster, and B. P. Lammers. 1999. Processing, mixing and particle size reduction of forages for dairy cattle. J. Anim. Sci. 77:180-186.

Jenkins, T. C., J. A. Bertrand, and W. C. Bridges, Jr. 1998. Interactions of tallow and hay particle size on yield and composition of milk from lactating Holstein cows. J. Dairy Sci. 81:1396-1402.

Johnson, L., J. H. Harrison, C. Hunt, K. Shinners, C. G. Doggett, and D. Sapienza. 1999. Nutritive value of corn silage as affected by maturity and mechanical processing: a contemporary review. J. Dairy Sci. 82:2813-2825.

Kalscheur, K. F, B. B. Teter, L. S. Piperova, and R. A. Erdman. 1997. Effect of dietary forage concentration and buffer addition on duodenal flow of trans-C18:1 FA and milk fat production in dairy cows. J. Dairy Sci. 80:2104-2114.

Leonardi, C., L. A. Armentano, and K. J. Shinners. 2001. Effect of different particle size distribution of oat silage on feeding behavior and productive performance of dairy cattle. J. Dairy Sci. 84(Suppl. 1):199. (Abstr.)

Mertens, D. R. 1997. Creating a system for meeting the fiber requirements of dairy cows. J. Dairy Sci. 80:1463-1481.

Mertens, D. R. 1999. Variation in aNDF results with modifications of the filter bag method. National Forage Testing Association, Technical Session Papers and Committee Reports to the Board and Membership, June 1999, Topeka, Kansas.

National Research Council. 1989. Nutrient Requirements of Dairy Cattle. 6th rev. ed. Natl. Acad. Sci., Washington, DC.

National Research Council. 2001. Nutrient Requirements of Dairy Cattle. 7th rev. ed. Natl. Acad. Press, Washington, DC.

Nordlund, K. V., and E. F. Garrett. 1994. Rumenocentesis: A technique for collection of rumen fluid for the diagnosis of subacute rumen acidosis in dairy herds. Bovine Pract. 28:109-112.

Onetti, S. G., R. D. Shaver, M. A. McGuire, and R. R. Grummer. 2001. Effect of type and level of dietary fat on rumen fermentation and performance of dairy cows fed corn silage-based diets. J. Dairy Sci. 84:2751-2759.

Onetti, S. G., R. D. Shaver, M. A. McGuire, D. L. Palmquist, and R. R. Grummer. 2002. Effect of supplemental tallow on performance of dairy cows fed diets with different corn silage:alfalfa silage ratios. J. Dairy Sci. 85:632-641.

Rode, L. M., and L. D. Satter. 1988. Effect of amount and length of alfalfa hay in diets containing barley or corn on site of digestion and rumen microbial protein synthesis in dairy cows. Can. J. Anim. Sci. 68:445-454.

Rojas-Bourrillon, A., J. R. Russel, A. Trenkle, and A. D. McGilliard. 1987. Effects of rolling on the composition and utilization by growing steers of whole-plant corn silage. J. Anim. Sci. 64:303311.

Ruppert, L. D., J. K. Drackley, D. R. Bremmer, and J. H. Clark. 2003. Effects of tallow in diets based on corn silage or alfalfa silage on digestion and nutrient use by lactating dairy cows. J. Dairy Sci. 86:593-609.

SAS User's Guide: Statistics, Version 7 Edition. 1998. SAS Inst., Inc., Cary, NC

Schwab, E. C., R. D. Shaver, K. J. Shinners, J. L. Lauer, and J. G. Coors. 2002. Processing and chop length effects in brown-midrib corn silage on intake, digestion, and milk production by dairy cows. J. Dairy Sci. 85:613-623.

Stine, C. M., H. A. Harland, S. T. Coulter, and R. Jenness. 1954. A modified peroxide test for detection of lipid oxidation in dairy products. J. Dairy Sci. 37:202-208.

Sukhija, P. S., and D. L. Palmquist. 1988. Rapid method for determination of total fatty acid content and composition of feedstuffs and feces. J. Agric. Food Chem. 36:1202-1206.

Timmermans, S. J., L. M. Johnson, J. H. Harrison, and D. Davidson. 2000. Estimation of the flow of microbial nitrogen to the duodenum using uric acid or allantoin. J. Dairy Sci. 83:1286-1299.

Wu, Z., and J. T. Huber. 1994. Relationship between dietary fat supplementation and milk protein concentration in lactation cows: A review. Livest. Prod. Sci. 39:141-155. 